\title{
PERANGKAP TIKUS DENGAN FASILITAS SHORT MESSAGE SERVICE ( SMS ) MENGGUNAKAN MIKROKONTROLLER ATmega8535
}

\author{
Dwika Aprilana ${ }^{1}$, Ageng Sadnowo $\mathbf{R}^{2}$, Helmy Fitriawan ${ }^{3}$. \\ 1,2,3 Jurusan Teknik Elektro Universitas Universitas Lampung \\ Jl. Prof. Sumantri Brojonegoro No.1 Bandar Lampung 35145 \\ 1dwika21@gmail.com,
}

\begin{abstract}
Abstrak- Perangkap tikus pada penelitian ini memiliki fasilitas short message service (sms) yang bertujuan untuk memberikan informasi secepatnya bahwa ada seekor tikus yang terperangkap. Hal ini berguna untuk mengurangi resiko penyebaran penyakit akibat kematian tikus. Fitur lain yang ada pada perangkap ini yaitu perangkap ini akan mengirim sms setiap satu jam secara berulang sampai pengguna perangkap ini mematikannya dengan cara melakukan panggilan telepon pada nomor telepon yang ada pada perankap tikus ini. Setelah melakukan semua rangkaian kegiatan penelitian didapatkan bahwa perangkap tikus ini dapat mengirimkan sms dalam waktu rata-rata 27,68 detik dan dapat mengulangi pengiriman sms selama 1 jam dengan waktu toleransi 7 detik.
\end{abstract}

Abstact- In this research mousetrap have short massage service facility that aims to give information quickly when rat is caught. This is useful for reducing the risk of death due to disease mouse. To know the rats are caught by using sensors photodiode that detects the presence of rats when infrared light direct to the photodiode blocked by mouse. Sending sms relay itself was controlled by microcontroller ATmega 8535 to move the keypad on the phone. Another features available on these traps are this trap will send sms repeated every one hour until this trap users deadly with a way to make phone calls on phone number that appears on this mousetrap.After a series of research found that this mousetrap can send sms in average time 27.68 seconds and can be repeated sms 1 hour delivery time 7 seconds tolerance.

Keyword : Short message service (sms), sensor, relay

\section{PENDAHULUAN}

Keberadaan hewan pengerat seperti tikus di rumah sangat tidak diharapkan bagi pemilik rumah. Untuk mengusir tikus tidaklah mudah, karena mereka umumnya hanya keluar pada malam hari. Terlebih tikus juga akan keluar saat kita tidak beraktifitas dan mereka juga akan leluasa aktif pada sudut-sudut rumah kita yang tidak terpantau, seperti : plafon rumah, gudang, lumbung padi. Wabah tikus banyak diakibat karena siklus reproduksi yang cepat. Dimana Tikus dan mencit mencapai umur dewasa sangat cepat, yaitu hanya 35 - 65 hari tikus sudah memasuki masa dewasa dan siap kawin. Selain itu masa kebuntingannya sangat pendek.

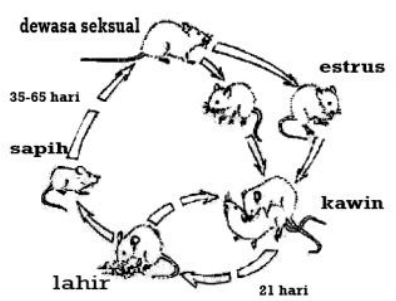

Gambar 1.1. Siklus Hidup Tikus

Dan hal ini terjadi berulang-ulang dengan jumlah anak yang banyak pada setiap kebuntingan. Jadi apabila pertumbuhan populasi tikus ini tidak dapat dikendalikan maka akan menjadi wabah yang merugikan manusia. ${ }^{[2]}$ 
Untuk itu diperlukan sebuah perangkap tikus yang dapat secara otomatis menginformasikan kepada kita bahwa ada tikus yang terperangkap tanpa kita harus memantau setiap saat. Selain itu perangkap ini sangat berguna untuk tempat yang susah untuk kita jangkau. Sehingga kita lebih efisien dalam memantau perangkap tikus, yaitu hanya menunggu informasi dari perangkap tikus tersebut.

Dengan kemampuan alat yang dapat menginformasikan kepada kita bahwa ada tikus yang terperangkap, maka kita tidak akan menemukan tikus dalam keadaan mati ataupun busuk dalam perangkap. Sehingga kita dapat meminimalisir resiko penyakit-penyakit yang disebarkan oleh kematian tikus tersebut.

Pada Penelitian ini akan merancang perangkap tikus elektronik yang dapat mendeteksi adanya tikus yang masuk ke perangkap. Dan perangkap ini akan mengirimkan informasi bahwa telah tertangkap seekor tikus melalui pesan singkat (SMS) ke nomor handphone tujuan. Pada penelitian ini akan menitik beratkan kepada waktu yang dibutuhkan perangkap ini dalam mengirim sms. Perangkap ini dirancang untuk dapat mengirim informasi secara berulang setiap 60 menit. Kemudian pengiriman baru akan berhenti jika handphone penerima melakukan misscall ke handphone yang berada diperangkap.

\section{TINJAUAN PUSTAKA}

\subsection{Perangkap Tikus Elektrik}

Ada juga sebagian orang menggunakan perangkap tikus konvensional. Alat perangkap tikus konvensional ini cukup murah. Penggunaan perangkap tikus ini sangat sederhana, dimana didalam perangkap tikus tersebut diletakkan makanan dan ketika tikus masuk kedalam perangkap tikus ini, maka tikus tersebut akan terperangkap dan tidak dapat keluar lagi. Setelah tertangkap tikus tersebut dibunuh dengan cara disiram air panas atau dipukul atau ada juga yang dibuang ke luar rumah.
Untuk perangkap tikus elektrik apabila terdapat tikus yang masuk ke perangkap, maka alat ini akan mengirimkan informasi tersebut melalui pesan singkat (SMS) ke nomor handphone yang telah disimpan dalam memori mikrokontroler. Media transmisi yang digunakan adalah jaringan telekomunikasi Global System for Mobile Communication (GSM).

Setelah menerima informasi SMS, maka si penerimaSMS ini dapat mengirimkan kembali SMS kontrol untuk membunuh tikus tersebut dengan cara memberikan kejutan listrik (disetrum) dengan tegangan 220 Volt. SMS kontrol tersebut dapat dikenali oleh sistem dan kemudian akan dijalankan perintah tersebut dengan cara mengaktifkan penyetrum listrik untuk membunuh tikus. ${ }^{[4]}$

Beberapa sistem yang dibutuhkan untuk menyusun sistem perangkap tikus berbasis mikrokontroler dengan fasilitas SMS yaitu sebagai berikut :

1. sensor Infra merah sebagai sistem Pendeteksi adanya objek tikus yang masuk ke dalam perangkap .

2. mikrokontroler sebagai sistem untuk mengirim dan menerima Data SMS ke dan dari handphone yang akan mengontrol alat ini.

3. Interface sebagai sistem untuk mengubah level tegangan TTL menjadi level RS-232 ataupun sebaliknya, agar data dari Handphone dapat dikenali oleh mikrokontroler.

4. Penyetrum tegangan 220 Volt.

5. catu daya untuk menghasilkan supply listrik ke sistem-sistem lainnya.

6. Handphone.

7. Kandang tikus

Hal yang membedakan Penelitian ini dari penelitian sebelumnya adalah :

1. Menghilangkan sub-sistem penyetrum $220 \mathrm{~V}$

2. Jenis Mikrokontroller yang digunakan. Di mana Pada penlitian sebelumnya digunakan Mikrokontroller AT89C51

3. Metode Pengiriman Sms,pada penelitian ini dengan cara mengganti 
penekanan tombol keypad dengan relay.

4. Pada Penelitian ini akan ditambah fitur pengingat memberi informasi bahwa ada tikus terperangkap untuk 60 menit sekali.

\subsection{Sensor Inframerah.}

Sensor inframerah yang digunakan adalah phototransistor. Seperti pada penelitian yang dilakukan oleh Endah Mulya Gustina Rahmat tentang "Kunci Elektris Sebagai Pengaman Pintu Rumah Tinggal dengan Menggunakan Mikrokontroller AT89S52". Pada penelitian menggunakan phototransistor yang dirangkai sebagai berikut :

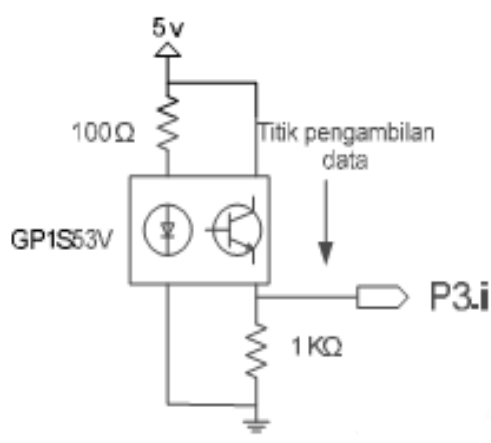

Gambar 2.1. Rangkaian Phototransistor

Dan didapatkan pada penelitian tersebut hasil pengujian sebagai berikut. ${ }^{[3]}$

Tabel 2.1.Uji Phototransistor

\begin{tabular}{|l|l|l|l|l|l|}
\hline Kondisi & P3.0(V) & P3.1(V) & P3.2(V) & P3.3(V) & P3.4(V) \\
\hline Tidak terhalang & 3,27 & 3,44 & 3,20 & 3,32 & 3,88 \\
\hline Terhalang & 0,87 & 0,88 & 0,87 & 0,88 & 0,87 \\
\hline
\end{tabular}

\subsection{Komparator}

Pada Sebuah penelitian yang berjudul Penentuan Level Air Tangki Dengan Sistem Kendali. Di sini terdapat terdapat 4 komparator yang setiap komparator mewakili setiap level tangki air. Pin COM terhubung pada kaki non-inverting disetiap comparator dan $\mathrm{Pin} \mathrm{Hi}$, Mid $\mathrm{Hi}$, Mid Lo, dan Lo terhubung pada kaki inverting comparator. Kaki non-inverting merupakan tegangan referensi yang menjadi acuan dalam menentukan adatidaknya air atau tinggi-rendahnya level air. Kondisi pengukuran tegangan untuk masing-masing masukan dan keluaran pada kaki comparator dapat dilihat pada Gambar 2.3 dan Tabel 2 memperlihatkan hasil pengukurannya. ${ }^{[1]}$

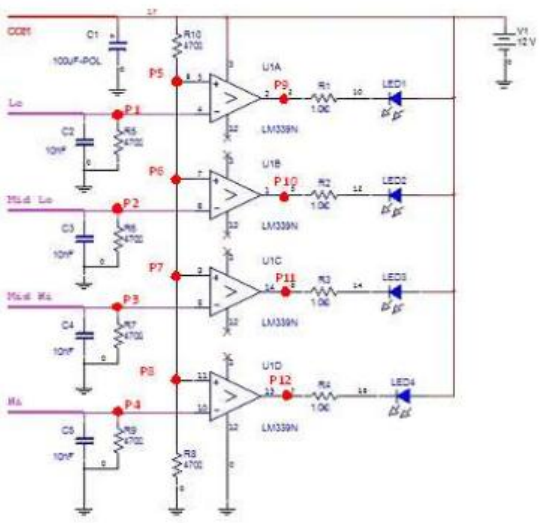

Gambar 2.2. Komparator

Tabel 2.2. Hasil Uji Komparator

\begin{tabular}{|c|c|c|c|c|c|}
\hline \multirow{2}{*}{$\begin{array}{c}\text { Keluar } \\
\text { an }\end{array}$} & \multirow{2}{*}{$\begin{array}{c}\mathbf{V}_{\text {REF }} \\
\text { ( Non- } \\
\text { inverting) }\end{array}$} & \multicolumn{2}{|c|}{$\begin{array}{c}\text { Masukan } \\
\text { Inverting (Px) }\end{array}$} & \multicolumn{2}{c|}{ Indikator LED } \\
\cline { 3 - 6 } & Low & High & Low & High \\
\hline P9 & $4.85 \mathrm{~V}$ & $8.5 \mathrm{~V}$ & $0.2 \mathrm{~V}$ & Off & On \\
\hline P10 & $4.85 \mathrm{~V}$ & $8.4 \mathrm{~V}$ & $0.2 \mathrm{~V}$ & Off & On \\
\hline P11 & $4.85 \mathrm{~V}$ & $8.3 \mathrm{~V}$ & $0.2 \mathrm{~V}$ & Off & On \\
\hline P12 & $4.85 \mathrm{~V}$ & $8.3 \mathrm{~V}$ & $0.2 \mathrm{~V}$ & Off & On \\
\hline
\end{tabular}

\subsection{Driver Relay (ULN 2003)}

Untuk menggerakan relay, daya dari microkontroller kurang mencukupi sehingga perlu penguat (driver). Driver relay yang paling sederhana biasanya terdiri dari sebuah transistor. ${ }^{[3]}$

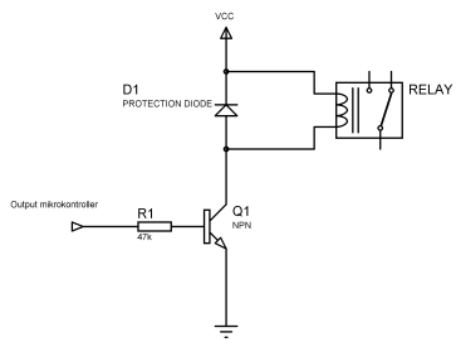

Gambar 2.3. Penguat Daya Sedehana

\section{Dioda Pengaman}

Fungsi dioda pada driver relay adalah sebagai pengaman untuk mencegah kick 
back, yaitu transient yang terjadi pada koil relai (beban induktif) saat relay dimatikan. Hal ini dapat dijelaskan menurut persamaan :

$$
V=L \frac{d i}{d t}
$$

Bila terjadi perubahan arus yang cukup besar dalam satuan waktu yang sangat cepat $(\mathrm{dt}=0)$ maka tegangan balik ini menjadi sangat besar, dan dapat mengakibatkan kerusakan pada transistor.

\section{METODOLOGI PENELITIAN}

\subsection{Diagram Blog}

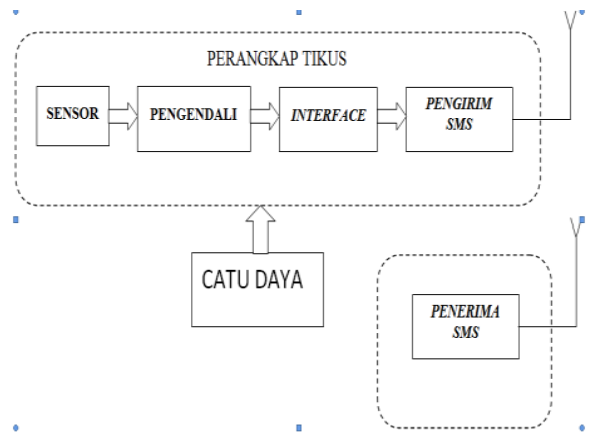

Gambar 3.1.Blok Diagram Perangkap Tikus

1. Sensor

Sensor memiliki fungsi untuk mendeteksi adanya tikus yang masuk ke dalam perangkap. Sensor yang digunakan fototransistor yang mendeteksi cahaya yang dihasilkan oleh led inframerah.

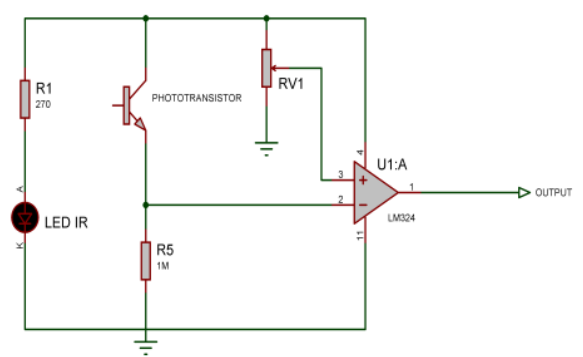

Gambar 3.2.Rangkaian Sensor Inframerah

2. Pengendali

Pengendali memiliki fungsi sebagai pusat kendali pendeteksian sensor inframerah dan pengendalian pengiriman SMS. Pengendali dalam perangkap disini menggunakan mikrokontroller ATmega8535.

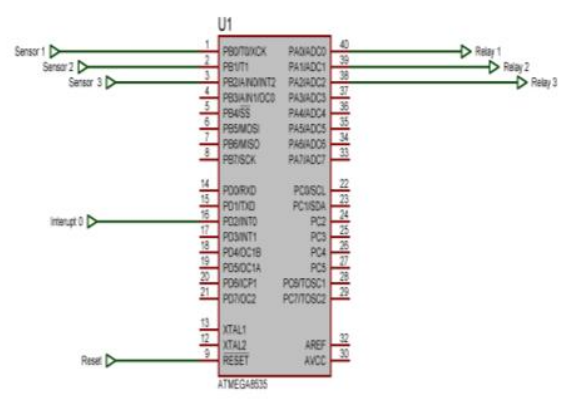

Gambar 3.3. Rangkaian Pengendali

\section{Interface.}

Interface berfungsi untuk melakukan pengiriman short message service (sms) pada handphone. Pada blok diagram ini terdapat beberapa relay yang berfungsi memberi perintah terhadap handphone untuk mengirim sms.

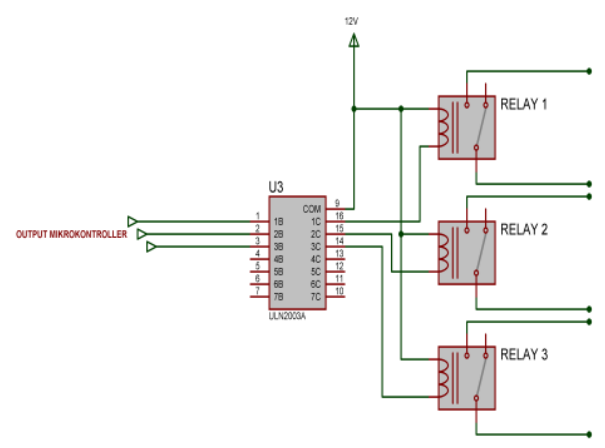

Gambar 3.4. Rangkaian Interface

Gambar 3.4 merupakan rangkaian interface terdiri dari tiga relay yang digunakan untuk memberi perintah kepada handphone untuk mengirim short massage service (sms) dengan cara menekan tombol keypad pada handphone. Untuk menggerakan relay ini, daya (arus/tegangan) dari mikrokontoler tidak mencukupi, sehingga digunakan driver relay berupa IC ULN2003. Tegangan output dari ULN2003 sendiri dapat disesuaikan dengan cara memberi tegangan yang dibutuhkan pada kaki 9 . 


\section{Pengirim SMS}

Informasi berupa teks dalam sms dikirim kepada penerima sms menggunakan handphone. Hondphone yang digunakan adalah Handphone Nokia type 1112 .

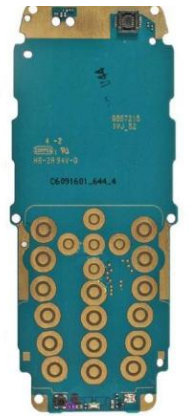

Gambar 3.5. Penampang Handphone

Handphone berfungsi untuk mengirimkan short message service (sms) dari perangkap kepada handphone penerima. Gambar 3.5 merupakan rangkaian PCB pada keypad handphone. Untuk satu keypad terdiri dari lingkaran dalam dan lingkaran luar. Keypad ini akan aktif apabila lingkaran dalam dan lingkaran luar terhubung. Dan untuk menghubungkanya menggunakan relay untuk mengaktifkan keypad.

\section{Catu Daya}

Catu daya di sini berfungsi sumber tegangan bagi blok lain.

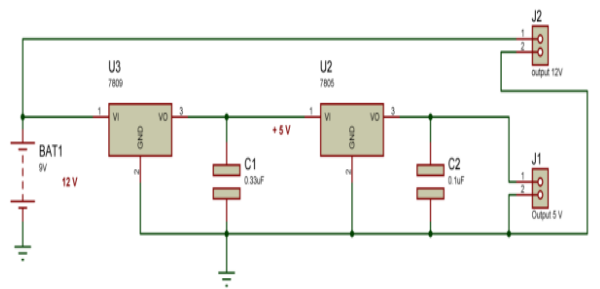

Gambar 3.6.Rangkaian Catu daya

Dapat dilihat dari Gambar 3.6 power supply pada perangkap tikus ini berasal dari aki yang memiliki tegangan $12 \mathrm{~V}$. Dan tegangan output yang dibutuhkan oleh sistem adalah tegangan $5 \mathrm{~V}$ dan $12 \mathrm{~V}$. Untuk mendapatkan tegangan $12 \mathrm{~V}$ didapat langsung dari aki yang digunakan.

\subsection{Flowchart Sistem}

Pada tugas akhir ini merancang perangkap tikus elektronis yang dapat mendeteksi adanya tikus yang masuk ke perangkap. Dan perangkap ini akan mengirimkan informasi bahwa telah tertangkap seekor tikus melalui pesan singkat (SMS) ke nomor handphone tujuan. Pada penelitian ini akan menitik beratkan kepada waktu yang dibutuhkan perangkap ini dalam mengirim sms. Perangkap ini dirancang untuk dapat mengirim informasi secara berulang setiap 60 menit. Kemudian pengiriman baru akan berhenti jika handphone penerima melakukan misscall ke handphone yang berada diperangkap.

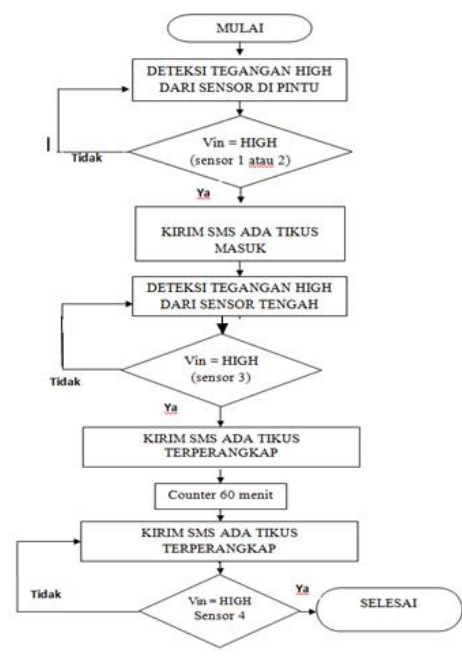

Gambar 3.7. Flowchart Sistem

\subsection{Rancang Bangun}

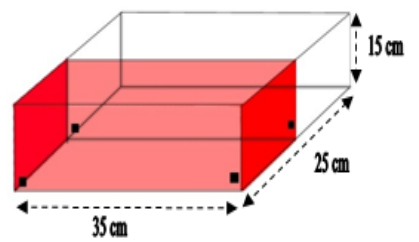

Gambar 3.8. Rancang Bangun

Keterangan :

$\square=$ Ruang rangkaian elektronik

$\square=$ Ruang perangkap tikus

口 $=$ Sensor 


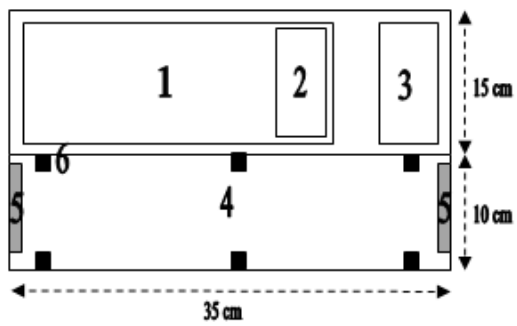

Gambar 3.9. Tampak atas

Keterangan :

$1=$ Rangkaian elektronik

$2=$ Handphone

$3=$ Accu

$4=$ Ruang perangkap tikus

$5=$ Pintu

$6=$ Sensor

\section{HASIL DAN PEMBAHASAN}

Perangkap ini dibuat agar dapat memberikan informasi secepat-cepatnya kepada pengguna perangkap tikus ini. Dan target pengiriman informasi dalam bentuk sms untuk perangkap ini yaitu tidak lebih dari 2 menit. Dari data Tabel 4.1 dapat dilihat bahwa pengiriman sms tidak lebih dari 2 menit. Dengan kata lain target penyampaian informasi tidak lebih dari 2 menit dapat tercapai. Dimana pengambilan data pengiriman sms ini dilakukan pada kualitas jaringan GSM yang baik (tidak ada penundaan pengiriman sms dan traffic jaringan normal)

Tabel 4.1. Waktu pengiriman sms

\begin{tabular}{|c|c|c|c|}
\hline $\begin{array}{l}\text { Rentan } \\
\text { Waktu }\end{array}$ & $\begin{array}{c}\text { Pukul } \\
\text { pengambilan } \\
\text { data }\end{array}$ & $\begin{array}{c}\text { Waktu } \\
\text { Pengiriman } \\
\text { SMS ke-1 }\end{array}$ & $\begin{array}{c}\text { Waktu } \\
\text { Pengiriman } \\
\text { SMS ke-2 }\end{array}$ \\
\hline \multirow{5}{*}{$\begin{array}{l}06.00 \\
\text { sampai } \\
12.00\end{array}$} & 06.21 & 26,97 & 44,08 \\
\hline & 08.10 & 28,91 & 45,85 \\
\hline & 09.23 & 28,29 & 45,17 \\
\hline & 10.32 & 27,46 & 44,97 \\
\hline & 11.28 & 28,13 & 45,24 \\
\hline \multirow{5}{*}{$\begin{array}{l}12.00 \\
\text { sampai } \\
18.00\end{array}$} & 12.04 & 27,40 & 46,89 \\
\hline & 14.07 & 27,78 & 45,05 \\
\hline & 15.24 & 27,65 & 45,41 \\
\hline & 16.14 & 27,86 & 44,02 \\
\hline & 17.19 & 27,34 & 45,09 \\
\hline \multirow{5}{*}{$\begin{array}{l}18.00 \\
\text { sampai } \\
00.00\end{array}$} & 19.01 & 27,93 & 45,51 \\
\hline & 20.46 & 27,58 & 45,79 \\
\hline & 21.36 & 27,43 & 44,82 \\
\hline & 22.54 & 27,98 & 44,06 \\
\hline & 23.51 & 27,45 & 43,93 \\
\hline \multirow{5}{*}{$\begin{array}{l}00.00 \\
\text { sampai } \\
06.00\end{array}$} & 01.23 & 27,68 & 44,12 \\
\hline & 02.21 & 27,16 & 44,39 \\
\hline & 03.49 & 27,35 & 45,05 \\
\hline & 04.29 & 27,86 & 44,47 \\
\hline & 05.22 & 27,42 & 45,59 \\
\hline
\end{tabular}

Dilihat dari Tabel 4.2 untuk mengamati perulangan sms untuk mengingatkan bahwa ada tikus yang terperangkap, kita melakukan pengamatan sebanyak tiga kali. Dan setiap pengamatan dilakukan pengulangan sebanyak lima kali. Dari data diatas dapat dilihat bahwa pengulangan yang terjadi hanya 2 kali pengulangan yang tepat 1 jam dari $15 \mathrm{kali}$ data pengulangan.

Tabel 4.2. Waktu pengulangan sms

\begin{tabular}{|l|c|c|c|c|c|}
\hline \multirow{2}{*}{ Hari ke- } & \multicolumn{5}{|c|}{ Waktu yang di butuhkan pengiriman sms (Pengulangan) } \\
\cline { 2 - 6 } & I & II & III & IV & V \\
\hline Hari pertama & $1: 00: 04$ & $1: 00: 05$ & $1: 00: 07$ & $1: 00: 05$ & $1: 00: 07$ \\
\hline Hari kedua & $1: 00: 03$ & $1: 00: 00$ & $1: 00: 01$ & $1: 00: 01$ & $1: 00: 00$ \\
\hline Hari Ketiga & $1: 00: 10$ & $1: 00: 11$ & $1: 00: 14$ & $1: 00: 13$ & $1: 00: 11$ \\
\hline
\end{tabular}

\section{V.KESIMPULAN}

Perancangan perangkap tikus elektronik yang berbasis mikrokontroller dengan fasilitas short message service ( sms ) telah berhasil dibuat sesuai spesifikasinya. Pada kualitas jaringan GSM yang baik, waktu yang diperlukan sistem ini dalam mengirim short message service (sms) pada yaitu 27,68 detik.

Serta perangkap berhasil mengirim informasi berulang setiap 60 menit dengan toleransi 6 detik.

\section{Daftar Pustaka}

[1] Achmad, Andani. A, Ejah, Umraeni. Penentuan Level Air Tangki Dengan Sistem Kendali. Jurnal ilmiah "Elektrikal Enjiniring" unhas. Volume 09/ No.02/Mei -Agustus/ 2011. Universitas Hasanudin. Makasar.2011

http://journal.unhas.ac.id/index.php/el en/article/download/676/575

[2] Ditjen PP \& PL. Pedoman Pengendalian Tikus : Khusus di Rumah Sakit.. Departemen Kesehatan RI. Jakarta. 2008 http://www.depkes.go.id/downloads/P engendalian\%20Tikus.pdf 
[3] Rahmat E.M.G. Kunci Elektris Sebagai Pengaman Pintu Rumah Tinggal Dengan Menggunakan Mikrokontroller AT89S52. Repository.Universitas Gunadarma. Jakarta.2005.

http://www.gunadarma.ac.id/library/ar ticles/graduate/industrial/technology/2 006/artikel_10401481.pdf

[4] Syamsudin, Eko., Wijono, F.X.sigit. , Gunawan, Hendra. Perangkap Tikus Menggunakan Mikrokontroler Dengan Fasilitas Short Message Service ( sms ). Jurnal. TESLA| VOL. 10 | NO. 2 | Petra. 2008 